\title{
Recherche d'une méthode d'analyse ethnologique de la cuisine
}

Hélène Balfet et Christian Pelras

\section{(2) OpenEdition \\ 12 Journals}

Édition électronique

URL : https://journals.openedition.org/tc/1039

DOI : $10.4000 /$ tc. 1039

ISSN : 1952-420X

Éditeur

Éditions de l'EHESS

Édition imprimée

Date de publication : 1 juin 1983

ISSN : 0248-6016

\section{Référence électronique}

Hélène Balfet et Christian Pelras, "Recherche d'une méthode d'analyse ethnologique de la cuisine », Techniques \& Culture [En ligne], 1 | 1983, mis en ligne le 26 janvier 2006, consulté le 29 septembre 2022. URL : http://journals.openedition.org/tc/1039; DOI : https://doi.org/10.4000/tc.1039

Ce document a été généré automatiquement le 29 septembre 2022.

Tous droits réservés 


\section{Recherche d'une méthode d'analyse ethnologique de la cuisine}

Hélène Balfet et Christian Pelras 